Stanisław Świtek, Łukasz Jankowiak, Zuzanna M. Rosin, Zuzanna Sawinska, Ryszard Steppa, Viktoria Takacs, Adam Zbyryt, Piotr Tryjanowski

\title{
Jak zachować wysoki poziom bioróżnorodności na obszarach rolniczych w Polsce? Identyfikacja najważniejszych problemów badawczych ${ }^{*}$
}

Streszczenie: Obszary rolnicze stanowią $60 \%$ powierzchni Polski i zaliczają się do terenów o najwyższym poziomie bioróżnorodności w Europie. Jednak wraz z intensyfikacją produkcji rolnej ich obecny stan jest bardzo zagrożony. Celem pracy jest wskazanie kluczowych problemów badawczych, które mogą pomóc w ochronie środowiska przyrodniczego polskich obszarów wiejskich. W tym celu od 45 osób związanych naukowo z tą tematyką

Mgr inż. Stanisław Świtek (autor korespondencyjny), Instytut Zoologii, Uniwersytet Przyrodniczy w Poznaniu, ul. Wojska Polskiego 71C, 60-637 Poznań, switek.stan@gmail.com; dr Lukasz Jankowiak, Katedra Zoologii Kręgowców i Antropologii, Instytut Badań nad Bioróżnorodnością, Uniwersytet Szczeciński, ul. Wąska 13, 71-415 Szczecin, jankowiakl@gmail.com; dr Zuzanna M. Rosin, Zakład Biologii Komórki, Instytut Biologii Eksperymentalnej, Uniwersytet im. Adama Mickiewicza, ul. Umultowska 89, 61-614 Poznań, zuzanna.rosin@gmail.com; dr inż. Zuzanna Sawinska, Katedra Agronomii, Uniwersytet Przyrodniczy w Poznaniu, ul. Dojazd 11, 60-632 Poznań, zuza.sawinska@gmail.com; dr hab. Ryszard Steppa, Katedra Turystyki Wiejskiej, Uniwersytet Przyrodniczy w Poznaniu, ul. Witosa 45, 60-637 Poznań, steppa@up.poznan.pl; dr Viktoria Takacs, Instytut Zoologii, Uniwersytet Przyrodniczy w Poznaniu, ul. Wojska Polskiego 71C, 60-637 Poznań, takacsviki@o2.pl; mgr inż. Adam Zbyryt, Polskie Towarzystwo Ochrony Ptaków, ul. Ciepła 17, 15-471 Białystok, adam.zbyryt@wp.pl; prof. dr hab. Piotr Tryjanowski, Instytut Zoologii, Uniwersytet Przyrodniczy w Poznaniu, ul. Wojska Polskiego 71C, 60-637 Poznań, piotr. tryjanowski@gmail.com.

* Badania zostały przeprowadzone w ramach projektu Liberation, 7 PR UE Cooperation nr kontraktu 311781 współfinansowanego ze środków Ministerstwa Nauki i Szkolnictwa Wyższego, umowa nr 3406/7. PR/2015/2. 
zebrano odpowiedzi na pytania, które przyporządkowano do jednego z siedmiu obszarów badawczych dotyczących odpowiednio: oceny stanu bioróżnorodności, efektywności polityki jej ochrony, wyboru pomiędzy tradycyjnym a intensywnym rolnictwem, czynników wpływających na decyzje rolników, znaczenia zwierząt gospodarskich, znaczenia zabudowań i infrastruktury oraz siedlisk w ochronie bioróżnorodności. Przedstawione problemy mają formę ogólną i liczymy, że mogą stanowić znaczące wprowadzenie do dalszej dyskusji pomiędzy decydentami a naukowcami. Jej podjęcie jest kluczowe dla skutecznej ochrony zasobów przyrodniczych krajobrazu rolniczego w Polsce.

Słowa kluczowe: krajobraz rolniczy, obszary wiejskie, ochrona przyrody, spadek bioróżnorodności.

\section{Wstęp}

Polska należy do krajów o najwyższym poziomie bioróżnorodności w Europie (CBD 2014). Zawdzięcza to wielu różnym czynnikom, od geograficznych, po te związane z historią i socjoekonomią. Położenie Polski na pograniczu klimatów kontynentalnego i atlantyckiego, różnorodność krain geograficznych oraz brak dużych naturalnych granic na zachodzie i wschodzie kraju sprzyjają różnorodności biologicznej. Ponadto rozwój ekonomiczny naszego kraju i idące za nim przekształcenia krajobrazu były długo hamowane ze względu na panujące warunki społeczno-ekonomiczne (komunizm).

Krajobraz Polski jest zdominowany przez obszary rolnicze - stanowią one $60 \%$ powierzchni kraju. Spośród 1,5 mln istniejących w Polsce gospodarstw rolnych aż 77\% to drobne gospodarstwa, których powierzchnia nie przekracza 10 ha (Dmochowska 2014). Charakter krajobrazu rolniczego zmienia się obecnie znacząco w naszym kraju ze względu na dwa wielkoskalowe procesy, intensyfikację rolnictwa i zmiany społeczno-ekonomiczne. Zwiększa się średnia powierzchnia gospodarstw, uprawiane są wysokowydajne rośliny i ich odmiany, używane są nawozy mineralne i chemiczne środki ochrony (Matson i in. 1997). Obszary rolnicze są jednak obecnie nie tylko miejscem życia i pracy rolników, ale także w coraz większym stopniu stanowią środowisko życia ludzi, którzy w tęsknocie za walorami przyrody przenoszą się z miasta na wieś. Wzrost statusu socjoekonomicznego mieszkańców obszarów wiejskich może negatywnie oddziaływać na różnorodność biologiczną (Rosin i in. 2016a).

Dzięki pracom naukowym prowadzonym w całej Europie mamy obecnie sporą wiedzę na temat wpływu intensyfikacji rolnictwa na bioróżnorodność, jednakże stale za mało badań poświęconych jest terenom rolniczym Polski i Europy Środkowo-Wschodniej (Tryjanowski i in. 2011). Aktualne rozważania powinny skupiać się 
wokół pytania, jak utrzymać tradycyjny charakter polskiego krajobrazu, w dobie silnych zmian społecznych i gospodarczych oraz znaczącego wsparcia finansowego ze strony Unii Europejskiej. Prace ukazujące się w czołowych czasopismach naukowych wskazują, że kluczowym krokiem jest włączenie czynników socjoekonomicznych do badań ekologicznych, jak też poznanie i zrozumienie społecznych oraz politycznych przeszkód w skutecznej ochronie przyrody (Cardinale i in. 2012). Ogromnym wyzwaniem jest wypracowanie na nowo modelu bezpośredniej zależności człowiek-przyroda, w której każda ze stron będzie zyskiwać (Fischer, Hartel, Kuemmerle 2012). Pomóc może w tym wskazanie obszarów problemowych, które wymagają większej uwagi naukowców, a także polityków i praktyków. Ważne jest to, by podejmowane działania i polityka w Europie opierały się na wynikach rzetelnych badań naukowych, ponieważ tylko w ten sposób zapewnimy skuteczność i adekwatność działań zmierzających do utrzymania i zwiększenia różnorodności biologicznej (Pullin i in. 2009; Gibbons, Wilson, Green 2011).

Pierwszym celem pracy jest wskazanie problemów badawczych związanych z ochroną bioróżnorodności polskich obszarów wiejskich. $Z$ uwagi na fakt, że opinie pojedynczych badaczy są często zależne od ich kompetencji, doświadczeń i realizowanych projektów, jak i chęci podkreślenia własnej oryginalności uwzględniliśmy opinie płynące $\mathrm{z}$ różnych środowisk. Następnie zebrane opinie pogrupowaliśmy w odpowiednich kategoriach i na podstawie przeglądu literatury przygotowaliśmy rozwinięcie zagadnień z obszaru każdej kategorii, co stanowiło drugi cel pracy.

Kluczową myślą przewodnią naszej pracy były uwagi Williama J. Sutherlanda i współpracowników (2011), wskazujące na potrzebę zmniejszania dystansu pomiędzy naukowcami, politykami a opinią publiczną w kontekście ochrony różnorodności biologicznej. Regularna, merytoryczna dyskusja pomiędzy tymi grupami jest niezbędna, ponieważ tylko w ten sposób możemy przełożyć wiedzę płynącą z badań naukowych na praktyczne rozwiązania i, co ważne, na ogólną świadomość potrzeby ochrony przyrody w społeczeństwie.

\section{Metodyka}

Do 56 osób pracujących w krajowych ośrodkach badawczych (uniwersytety, instytuty resortowe i instytuty PAN), związanych zawodowo $\mathrm{z}$ ochroną środowiska przyrodniczego i publikujących artykuły naukowe z tematyki ekologii i ochrony środowiska obszarów rolniczych, został rozesłany drogą elektroniczną list z prośbą o wskazanie od trzech do pięciu najważniejszych problemów badawczych związanych z ochroną środowiska obszarów rolniczych w Polsce. Wiadomości zwrotne otrzymano od 45 osób (80\% respondentów). Pytania dotyczyły m.in. poznania wartości różnorodności biologicznej, czynników wpływających istotnie na 
przyrodę, a także skuteczności podejmowanych działań ochronnych. W sumie zgłoszono 162 pytania. Wszystkie otrzymane wiadomości zostały przeanalizowane i zakwalifikowane do jednego z następujących obszarów tematycznych: (1) Ogólne kwestie dotyczące oceny i zachowania bioróżnorodności; (2) Efektywność polityki w ochronie bioróżnorodności; (3) Intensywne czy tradycyjne rolnictwo - gdzie jest nasza przyszłość?; (4) Indywidualne decyzje rolników; (5) Znaczenie zwierząt gospodarskich; (6) Znaczenie zabudowań i infrastruktury w kształtowaniu bioróżnorodności; (7) Znaczenie siedlisk nieużytkowanych rolniczo. Podstawą do wyznaczenia powyższych obszarów był zakres tematyczny zgłoszonych pytań oraz wiedza i doświadczenie autorów niniejszej pracy. Merytorycznie tożsame pytania łączono w obrębie obszarów tematycznych, w efekcie czego otrzymano 29 pytań (od trzech do pięciu pytań na obszar tematyczny).

\section{Wyniki i dyskusja}

Finalnym punktem pracy było rozwinięcie poruszanych problemów w ramach podrozdziałów odpowiadających obszarom tematycznym. W każdym podrozdziale przedstawiono cząstkowe wyniki wraz z dyskusją nad ich znaczeniem oraz implikacjami dla różnorodności biologicznej krajobrazu rolniczego w Polsce.

\subsection{Ogólne kwestie dotyczące oceny i zachowania bioróżnorodności w krajobrazie rolniczym}

1. Jaki jest stan bioróżnorodności obszarów rolniczych?

2. W jakim tempie tracimy zasoby przyrodnicze?

3. Jak chronić różnorodność gatunkową poszczególnych grup zwierząt?

4. Jaki jest najlepszy sposób na promocję ochrony zasobów przyrodniczych?

5. Jak wycenić dobro publiczne, jakim jest bioróżnorodność?

Polska stanowi ważny zasób populacji wielu gatunków związanych z europejskim ekstensywnym krajobrazem rolniczym, np. bociana białego (Ciconia ciconia; 38\%), wodniczki (Acrocephalus paludicola; 90\%) czy skowronka (Alauda arvensis; 21\%) (Wilk i in. 2010). Jednakże intensyfikacja rolnictwa następująca w ostatnich latach odcisnęła się negatywnie na bioróżnorodności krajobrazu rolniczego Polski (Tryjanowski i in. 2011; Rosin i in. 2016a). W wyniku transformacji krajobrazu i usuwania cennych siedlisk wiele gatunków roślin i zwierząt wykazuje obecnie silne spadkowe trendy (Neubauer, Chodkiewicz, Chylarecki 2014). Tempo, w jakim tracimy bioróżnorodność krajobrazu rolniczego w naszym kraju, wykazują m.in. ogólnopolskie monitoringi ptaków. Indeks zmiany stanu populacji pospolitych ptaków krajobrazu rolniczego, na który składają się wskaźniki liczebności 
22 gatunków ptaków związanych z krajobrazem rolniczym (FBI, Farmland Bird Index), wykazał 15-procentowy spadek między latami 2000 i 2014 (Neubauer, Chodkiewicz, Chylarecki 2014). Do gatunków wykazujących najsilniejsze trendy spadkowe w Polsce należą m.in. świergotek polny (Anthus campestris), szczygieł (Carduelis carduelis), trznadel (Emberiza citrinella), cierniówka (Curruca communis), pokląskwa (Saxicola rubetra), czajka (Vanellus vanellus), kuropatwa (Perdix perdix) i przepiórka (Coturnix coturnix) (Chodkiewicz i in. 2013). Niektóre gatunki jednak zwiększają swoje liczebności, np. dzwoniec (Chloris chloris), potrzeszcz (Emberiza calandra), mazurek (Passer montanus), żuraw (Grus grus) (Chodkiewicz i in. 2013).

Szybko postępujące negatywne zmiany w polskim krajobrazie rolniczym przypominają te, które nastąpiły w Europie Zachodniej kilka dekad temu. Obecnie największym wyzwaniem jest wypracowanie takiego wzorca gospodarowania, by zapewnić ochronę wielu grupom zwierząt, z których niemal każda pełni ważne funkcje ekosystemowe (Gagic i in. 2015). Różne taksony mają różne wymagania siedliskowe i związane są z różnymi typami pokrycia terenu, stąd struktura krajobrazu sprzyjająca jednej grupie może być mało korzystna dla innej, prowadząc do homogenizacji gatunkowej (Wolters, Bengtsson, Zaitsev 2006; Gagné, Fahrig 2011; Fahrig i in. 2015). Czy zatem możliwe jest gospodarowanie krajobrazem tak, by chronić jednocześnie różne grupy zwierząt i gatunki wykazujące odmienne preferencje wobec typów pokrycia terenu (Fahrig i in. 2015)? Dobrym rozwiązaniem wydaje się być podniesienie heterogeniczności struktury krajobrazu, poprzez zwiększenie różnorodności typów pokrycia terenu oraz złożoności przestrzennego wzorca ich występowania (Fahrig i in. 2015). Potwierdzają to klasyczne badania prowadzone na kilku różnych grupach zwierząt jednocześnie, gdzie relacje pomiędzy różnorodnością biologiczną w obrębie grup (np. ptaków, motyli, chrząszczy) a intensyfikacją użytkowania gruntów oraz uproszczeniem struktury krajobrazu przyjmują w większości ten sam, negatywny kierunek (np. Flohre i in. 2011; Fahrig i in. 2015). Niemniej jednak badania skupiające się na poszczególnych grupach zwierząt są potrzebne, szczególnie w przypadku tych taksonów, które mają wąskie wymagania siedliskowe, a którym poświęcono dotąd mało uwagi w kontekście ochrony krajobrazu rolniczego, np. pająków (przykładowo baza publikacji naukowych Scopus wykazuje 92 pozycje dla hasła „farmland and spiders”, podczas gdy aż 1624 pozycji - dla hasła „farmland and birds”).

Wypracowano szeroki wachlarz narzędzi ekonomicznych przeznaczonych do wyceny wartości całych ekosystemów, tych naturalnych i opartych na gospodarowaniu, a także oceny świadczeń, jakie zapewniają (Naido, Iwamura 2007; de Groot i in. 2012). Ciągle jednak bardzo mało wiemy o ekonomicznych konsekwencjach spadku różnorodności biologicznej równoznacznej z redukcją różnorodności genetycznej, 
taksonomicznej i funkcjonalnej. Wycena funkcji ekosystemowych (naturalnych procesów będących podstawą świadczeń ekosystemowych) jest trudna, szczególnie w systemach rolniczych, gdzie naturalne procesy są często silnie zmieniane i upraszczane przez działalność człowieka (Rosin i in. 2011). Wycena szkód w świadczeniach ekosystemowych będących efektem spadku bioróżnorodności musi brać pod uwage powiązania różnorodność biologiczna - funkcje ekosystemowe - świadczenia ekosystemowe (Cardinale i in. 2012). Co więcej, mechanizmy będące podstawą świadczeń ekosystemowych są stale słabo poznane, a ich bezpośrednia wycena czy manipulacje eksperymentalne w warunkach naturalnych są wręcz niemożliwe (Rosin i in. 2011; Cardinale i in. 2012). Ogromnym wyzwaniem jest zatem poznanie bezpośrednich zależności pomiędzy różnorodnością biologiczną a świadczeniami ekosystemowymi (Rosin i in. 2011; Cardinale i in. 2012). Włączenie ekonomii do ochrony przyrody jest niewątpliwie potrzebne, ale niesie również zagrożenie akceptowania postawy, w ramach której wartość przyrody jest postrzegana wyłącznie przez pryzmat wymiernych korzyści, jakie oferuje człowiekowi (finansowych, estetycznych, kulturowych itd.; Rosin i in. 2011; Morelli, Møller 2015).

\subsection{Efektywność polityki w ochronie bioróżnorodności}

6. Jaki realny wpływ na środowisko mają fundusze przeznaczane na jego ochronę (np. Natura 2000, LIFE)?

7. Jak polityka UE i Polski wpłynęła na stan środowiska rolniczego w naszym kraju po roku 2004?

8. Jaka jest efektywność programów rolnośrodowiskowych?

9. Czy regulacje prawne ograniczające obrót ziemią mają wpływ na różnorodność biologiczną?

Najważniejszym mechanizmem finansowym Wspólnej Polityki Rolnej (WPR) UE mającym na celu zachowanie różnorodności biologicznej krajobrazu rolniczego w Europie są programy rolnośrodowiskowe, których zadaniem jest subsydiowanie tych rolników, którzy chcą ekstensyfikować działalność rolniczą na części swoich ziem. Do założeń programu należą takie zadania, jak zachowanie cennych siedlisk przyrodniczych, ich odtworzenie, podniesienie świadomości ekologicznej (Sawicka, Hameed, Noaema 2016). Poza kilkoma wyjątkami większość z nich nie spełniła roli dotyczącej zwiększenia lub zatrzymania spadku kluczowych gatunków ptaków zasiedlających obszary rolnicze (np. Żmihorski i in. 2016). Dużym źródłem finansowania jest fundusz LIFE, który ma na celu zachowanie różnorodności biologicznej i zrównoważony rozwój (LIFE 2016). Projekty LIFE skupiają się na zachowaniu lub poprawie właściwego stanu zachowania przedmiotów ochrony na obszarach Natura 2000, a te zrealizowane dotychczas w Polsce wskazują, że jest to efektywny sposób 
ochrony ptaków związanych z krajobrazem rolniczym (Lachmann, Marczakiewicz, Grzywaczewski 2010; Zbyryt i in. 2014; Zbyryt i in. 2016). Niewiele jednak wyników i efektów ekologicznych projektów LIFE realizowanych w Polsce zostaje podsumowanych w postaci artykułów naukowych.

W Polsce wzrasta przeciętna powierzchnia gospodarstwa rolnego (GUS 2013a). Wraz ze wzrostem powierzchni działek spada bogactwo zbiorowisk roślinnych w gospodarstwach rolnych (Štefanová, Śálek 2014). Ponadto specjalizacja i zwiększenie produktywności związane ze zwiększeniem mechanizacji i chemizacji rolnictwa prowadzą do spadku bioróżnorodności na terenach rolniczych (Benton i in. 2002; Newton 2004). Pomimo stosowania programów rolnośrodowiskowych w całym kraju odnotowuje się postępujący spadek bogactwa gatunkowego i liczebności ptaków krajobrazu rolniczego (Neubauer i in. 2015). Obszary, na których w największym stopniu były realizowane dotychczas te programy, to północno-wschodnia, północna i zachodnia Polska (Kotowska, Żmihorski 2016). Pokrywają się one $\mathrm{z}$ terenami o największej intensyfikacji rolnictwa w kraju (Chylarecki, Jawińska, Kuczyński 2006). Programy rolnośrodowiskowe w większości krajów UE, gdzie dotychczas były realizowane, nie przyniosły żadnego efektu lub był on bardzo niewielki (Batary i in. 2015). Pojedyncze przypadki wskazują nawet, że był on negatywny (Breeuwer i in. 2009; Whittingham 2011), a bardzo nieliczne, że wpłynęły zdecydowanie pozytywnie na lokalną bioróżnorodność (Hiron i in. 2013a; Marja i in. 2014). Monitoring skuteczności działań podejmowanych w ramach programów rolnośrodowiskowych w Polsce wykazał, że nie sprzyjały one większości gatunków kwalifikujących do tych programów (10 gatunków ptaków). Opóźnienie koszenia, jeden z wymogów programu, wpłynęło pozytywnie jedynie na derkacza (Crex crex) (Kotowska, Żmihorski 2016). Nie znaleziono pozytywnego związku pomiędzy płatnościami rolnośrodowiskowymi a bogactwem lub występowaniem gatunków kwalifikujących do programu na obszarach Natura 2000 i poza nimi (Żmihorski i in. 2016). Wykazano natomiast, że tereny poddane monitoringowi znajdujące się poza siecią Natura 2000 są co najmniej równie cenne lub nawet bogatsze w gatunki ptaków kwalifikujących do płatności rolnośrodowiskowych niż działki w granicach obszarów Natura 2000. Za jedną z przyczyn bardzo niskiej efektywności programów rolnośrodowiskowych uznano niewielką skalę prowadzenia zabiegów ochronnych (Kotowska, Żmihorski 2016). Dopłaty UE z filaru I i II WPR powinny być traktowane z dużą ostrożnością nie tylko dlatego, że rozwiązania płynące z Europy Zachodniej są często nieadekwatne do specyfiki naszych obszarów (Tryjanowski i in. 2011), ale z uwagi na to, że jest to utrzymywanie sztucznej zależności - „będzie przyjaźnie wobec przyrody dopóki będzie finansowe wsparcie z UE” (Fischer, Hartel, Kuemmerle 2012). 
Jedna z regulacji, która może mieć wpływ na stan środowiska, to ograniczenia dotyczące obrotem ziemi wprowadzone w kilku krajach należących do Wspólnoty Europejskiej, np. w Polsce, Danii, Finlandii, Chorwacji (EURO-Lex 2016). Zbyt krótki czas obowiązywania tych przepisów w Polsce nie pozwala jeszcze na ocenę tego rozwiązania. Wydaje się, że planowane wspieranie w zakupie ziemi w pierwszej kolejności lokalnych, drobnych rolników może przynieść pozytywny skutek w spowolnieniu procesu utraty różnorodności biologicznej na terenach rolniczych (Benton i in. 2003; Newton 2004; Ziętara 2014).

\subsection{Intensywne czy tradycyjne rolnictwo - gdzie jest nasza przyszłość?}

10. Jak zachować balans pomiędzy produkcją rolniczą a ochroną środowiska?

11. Jaki wpływ na produkcję rolniczą będzie mieć postęp technologiczny, zmniejszająca się opłacalność produkcji, zmiany demograficzne i zmieniający się klimat?

12. Jaka jest przyszłość polskiego rolnictwa i czy istnieje alternatywa dla jego intensyfikacji?

13. Które $\mathrm{z}$ tradycyjnych metod rolnictwa powinny być przywrócone i mogłyby służyć w ochronie bioróżnorodności i środowiska?

W minionym wieku nastąpiła silna intensyfikacja rolnictwa, a zmiana ta miała praktycznie charakter globalny. W pierwszej kolejności zwiększenie produkcji rolniczej polegało na przeznaczeniu pod uprawę rolniczą nowych terenów: w ciągu 300 lat zwiększyła się ona czterokrotnie w skali całego globu. W drugiej kolejności zwiększano wydajność produkcji żywności poprzez wprowadzanie wysokoplonujących odmian roślin, nawożenie mineralne, stosowanie pestycydów itd. Związane z tymi zmianami przekształcenia krajobrazu i ingerencja w środowisko spowodowały wiele poważnych negatywnych konsekwencji środowiskowych, takich jak erozja, zmniejszenie żyzności gleby, spływy powierzchniowe, spadek bioróżnorodności (Matson i in. 1997). Na świecie toczy się obecnie debata, której celem jest znalezienie rozwiązania problemu pogodzenia rosnącego zapotrzebowania na wysokokaloryczną żywność ze zrównoważoną dla środowiska jej produkcją (Seufert, Ramankutty, Foley 2012). Jedną z możliwości jest zastosowanie agroekologicznych praktyk, takich jak stosowanie nawozów naturalnych, dobór i zmianowanie roślin, siew międzyplonów, płodozmian, siew bezpośredni oraz wykorzystanie otaczającego krajobrazu i jego elementów. Są one w różnym stopniu wdrażane w praktyce (Wezel i in. 2014). Rolnictwo ekologiczne charakteryzuje się zredukowanym negatywnym wpływem na środowisko (Birkhofer, Smith, Rundlof 2016). Taki model rolnictwa wymaga jednak badań i działań w kierunku minimalizowania różnicy w wielkości plonów w porównaniu do rolnictwa konwencjonalnego, opartego 
na intensyfikacji produkcji (Ponsio, Kremen 2016). W krajach, gdzie dominuje intensywne rolnictwo, rolnicy stanowią niewielką grupę społeczeństwa i mają stosunkowo wysokie dochody (Alstion, Parday 2014). Ponadto krytycy rolnictwa ekologicznego argumentują, że wymaga ono znacząco więcej powierzchni pod uprawę, by wyrównać zmniejszone plony, jakie dostarcza (Seufert, Ramankutty, Foley 2012). Równocześnie nie dostrzegają oni faktu, że już teraz produkujemy żywność w ilościach przekraczających potrzeby globalnej populacji ludzkiej, jednakże $\mathrm{z}$ uwagi na dużą nierównowagę $\mathrm{w}$ alokacji żywności w różnych częściach świata nie potrafimy pozbyć się problemu głodu (Seufert, Ramankutty, Foley 2012). W innym proponowanym modelu produkcji żywność ma być produkowana równolegle i podzielona przestrzennie, na obszary intensywnie użytkowane i gospodarstwa ekologiczne (Leifeld 2016). Współczesne, intensywne rolnictwo jest wysokowydajne, a jedną z konsekwencji jego charakteru jest również wysokie zapotrzebowanie na energię. Zrównoważony rozwój rolnictwa musi więc uwzględniać nieodnawialność paliw, z których korzysta, i zakładać poszukiwanie nowych źródeł energii (Bardi, El Asmar, Lavacchi 2013). Ponadto produkcja żywności jest działem ekonomii, który najsilniej „odczuwa” zmiany klimatyczne.

\subsection{Indywidualne decyzje rolników}

14. Jak rolnicy oceniają potrzebę zachowania i tworzenia ostoi bioróżnorodności na ich ziemi i czym to jest powodowane?

15. Co może skłonić rolników do tego, by chcieli chronić wartości przyrodnicze swojej ziemi?

16. Jakie korzyści odnosi rolnik z ochrony przyrody i jaką przedstawia ona dla niego wartość?

17. Jaką rolę w świadomości dotyczącej ochrony przyrody odgrywają przekonania religijne i światopogląd?

18. Jak ekonomia produkcji w rolnictwie wpływa na środowisko?

Podstawowym problemem w ochronie obszarów rolniczych jest rozbieżność interesów między osobami zajmującymi się ochroną przyrody a rolnikami. Pierwsi postulują ekstensyfikację, a drudzy dążą do intensyfikacji rolnictwa. Badania ankietowe wskazują, że programy rolnośrodowiskowe nie wpływają znacząco na zmianę postrzegania problemów zaniku bioróżnorodności: ochrona przyrody jest nadal nieistotna z punktu widzenia rolników (Mroczek i in. 2013). Świadomość ekologiczna indywidualnych rolników nie zależy od wykształcenia oraz od wielkości gospodarstwa rolnego (Pisarek i in. 2016). Można więc powiedzieć, że stoimy przed dość trudnym problemem, który wynika głównie z małej świadomości rolników dotyczącej zagrożenia związanego $\mathrm{z}$ utratą różnorodności biologicznej na terenach 
rolniczych (Pisarek i in. 2016). Większosśc rolników uważa, że metody proekologiczne wiążą się z dużym nakładem czasu oraz ich nieopłacalnością (Pisarek i in. 2016). Podsumowując, bez rekompensat finansowych przeciętny rolnik nie będzie chronił przyrody.

$\mathrm{Na}$ obszarach wiejskich obserwuje się obecnie wzrost przeciętnej wielkości gospodarstwa rolnego (Bański 2014). Małe gospodarstwa rolne (poniżej 5 ha) w niewielkim stopniu spełniają funkcje produkcyjne. Bardzo ważna są natomiast ich funkcje: społeczna, środowiskowa oraz estetyczna - zachowania charakteru krajobrazu rolniczego (Żmija, Szafrańska 2015). Zanikanie małych gospodarstw w połączeniu z trendem starzenia się społeczności oraz odpływem młodej i aktywnej ludności wiejskiej w perspektywie najbliższych dekad może trwale zmienić obraz wsi (GUS 2013b). Dlatego tak ważne jest zabieganie o poszerzenie świadomości przyrodniczej wśród rolników i pozostałych mieszkańców obszarów wiejskich. $\mathrm{Na}$ problem braku świadomości ekologicznej rolników warto spojrzeć szerzej, także w kontekście kulturowo-religijnym. Z badań CBOS (Boguszewski 2013) wynika, że w hierarchii wartości przeciętnego Polaka wiara znajduje się na siódmym miejscu najczęściej wybieranych wartości, po rodzinie, zdrowiu, uczciwym życiu, pracy zawodowej, spokoju i szacunku do innych ludzi. Co ciekawe, wiara bywa ważniejsza aniżeli dobrobyt czy bogactwo. Znajduje się ona wyżej w hierarchii wartości społeczeństw wiejskich niż miejskich. Osoby niepraktykujące w większym stopniu cenią sobie status ekonomiczny. Zatem religijność polskiej wsi może być jednym ze sposobów poszerzania świadomości ekologicznej rolników i pozostałych mieszkańców obszarów rolniczych. Temat ochrony przyrody ma swoje miejsce w teologii chrześcijańskiej, która oparta jest na poglądach wielkiego filozofa religii chrześcijańskiej św. Franciszka (Dołęga 1997). W teologii katolickiej funkcjonuje pojęcie tzw. grzechu ekologicznego, zdefiniowanego jako „zło, które burzy ludzki świat" (Bajda 1995).

\subsection{Znaczenie zwierząt gospodarskich}

19. Jakie gatunki i rasy zwierząt mają największą wartość dla ochrony krajobrazu i zachowania bioróżnorodności obszarów rolniczych?

20. Który z możliwych sposobów utrzymania zwierząt jest najbardziej korzystny dla zachowania bioróżnorodności?

21. Jaką rolę odgrywa wypas zwierząt gospodarskich dla bioróżnorodności i człowieka?

Chów zwierząt gospodarskich odgrywa ważną rolę w ochronie krajobrazu rolniczego i zachowaniu bioróżnorodności. Przeżuwacze, głównie owce i kozy, są szczególnie cenne w tym kontekście. Przeżuwacze mogą i powinny wykorzystywać 
pasze mające niską wartość odżywczą i ekonomiczną dla człowieka. Małe przeżuwacze są doskonale przystosowane do przemieszczania się na duże odległości, a wiele ras, szczególnie tych, które reprezentują wszechstronny typ użytkowy, dobrze znosi niekorzystne warunki środowiskowe, czyli duże opady, skąpe żywienie czy brak zadaszeń na pastwiskach (Niżnikowski i in. 2015). Bydło mleczne użytkowane intensywnie coraz rzadziej korzysta z trwałych użytków zielonych, jednak bydło mięsne i mięsno-mleczne, np. simentalskie, czy krowy rasy polskiej czerwonej można coraz częściej spotkać w polskim krajobrazie rolniczym. Szczególna rola w ochronie krajobrazu powinna przypadać rasom rodzimym, objętym programem ochrony zasobów genetycznych, jako tym najlepiej przystosowanym do miejscowych warunków środowiskowych, potrafiącym wykorzystywać często ubogą bazę paszową (Small 2002; Gruszecki, Krupiński 2016).

Ważnym aspektem poruszanego tematu w kontekście ochrony przyrody jest intensywność chowu zwierząt. Intensywne systemy produkcji wymagają mniejszego areału, są bardziej pracochłonne, wykorzystuje się w nich międzynarodowe rasy zwierząt (Cassandro 2014). Natomiast w systemach ekstensywnych produkcja rolnicza jest realizowana na większych areałach, które mogą zrekompensować uzyskiwanie niższych plonów. Na niektórych terenach w Europie pastwiskowe systemy utrzymania zwierząt mają istotne znaczenie, a same zwierzęta stanowią element kulturowy (Broom, Galindo, Murgueitio 2013). Przykładem takiego regionu może być Podhale (Mroczkowski 2005). Zachowaniu różnorodności biologicznej środowiska rolniczego sprzyjają systemy, w których wypasa się zwierzęta na trwałych użytkach zielonych. Zaniechanie wypasu zwierząt jest przyczyną sukcesji wtórnej przejawiającej się stopniowym zarastaniem nieużytkowanej powierzchni m.in. przez krzewy i drzewa, co wiąże się z utratą charakteru otwartego krajobrazu i wycofywaniem się gatunków zwierząt z nim związanych (np. ptaków siewkowych). Problem ten coraz silniej dotyka użytki zielone w dużych dolinach rzecznych w Polsce. Dlatego tak ważne jest wypasanie bydła, owiec i kóz, które ograniczają nadmierny rozwój krzewów, sprzyjając zarazem rozwojowi roślinności zielnej (Pinto-Correia, Mascarenhas 1999). Przykładowo na Półwyspie Iberyjskim w celu ochrony krajobrazu rolniczego wykorzystuje się owce, kozy, bydło i świnie. W Niemczech w okolicach Lünneburga od wielu lat wypas owiec służy utrzymaniu tamtejszych wrzosowisk. Na terenach dawnych poligonów wojskowych podejmuje się badania nad efektami wspólnego wypasu bydła i owiec w kontekście ochrony krajobrazu (Putfarken i in. 2008). W Polsce prowadzone są badania dotyczące ochrony muraw kserotermicznych przy wykorzystaniu owiec rasy wrzosówka (Bernacka i in. 2013). Jednakże pogłowie owiec w Polsce jest obecnie niewielkie i wynosi 236 tys. sztuk (GUS 2016). 
Wypasanie zwierząt ma też znaczenie kulturowo-społeczne. Użytkowana na południu Polski polska owca górska odmiany białej i barwnej dostarcza mleka służącego do wyrobu regionalnych serów, a wełna tych owiec wykorzystywana jest do wyrobu strojów regionalnych i wyrobów dekoracyjnych (Szulc 2011). Wypasanie zwierząt powinno być szeroko propagowane ze względu na jego rolę nie tylko w utrzymaniu bioróżnorodności krajobrazu rolniczego, ale również w kulturze regionalnej. Duże znaczenie ma też dostarczanie regionalnych produktów spożywczych, które wyróżniają się wysoką jakością w porównaniu do produktów otrzymywanych w gospodarstwach nastawionych na intensywną produkcję (Peters 2006; Vicini i in. 2008; Carrasco i in. 2009).

\subsection{Znaczenie zabudowań i infrastruktury w kształtowaniu bioróżnorodności}

22. Jaki jest wpływ infrastruktury (np. farm wiatrowych) na bioróżnorodność, w tym na ptaki?

23. Jak zabudowa wiejska i jej zmiany wpływają na zwierzęta?

24. Czy różnorodny krajobraz może wywierać wpływ na zróżnicowanie genetyczne i poziom stresu u zwierząt?

25. Jak krajobraz rolniczy oddziałuje na produkcję rolniczą i różnorodność gatunków go zasiedlających?

Struktura krajobrazu jest jednym z ważniejszych elementów wpływających na poziom bioróżnorodności. Każda ingerencja w jego charakter niesie ze sobą zmiany w składzie gatunkowym zespołów ją zasiedlających. Przykładem mogą być linie elektroenergetyczne, które stały się stałym elementem krajobrazu, a ich obecność nie pozostaje bez znaczenia dla niektórych gatunków ptaków, np. bociana białego (Tryjanowski i in. 2014). Kolizje ptaków z elementami sieci elektroenergetycznej to jedna z ważniejszych przyczyn śmiertelności tych zwierząt. Ponadto takie zdarzenia wiążą się również z przerwami w dostawie prądu i stratami materialnymi (Kaługa, Sparks, Tryjanowski 2011). Innym przykładem infrastruktury obecnej w polskim krajobrazie są turbiny wiatrowe, które wykazują zwykle negatywny wpływ na zwierzęta. Negatywne efekty tych struktur wiążą się przede wszystkim z kolizjami, a także oddziaływaniem na różne aspekty biologii lęgowej ptaków, m.in. parametry śpiewu tokujących samców (Barrios, Rodriguez 2004; Leddy, Higgins, Naugle 1999; Saidur i in. 2011; Rosin i in. 2016b; Szymański i in. 2017). $\mathrm{Z}$ tego powodu nie powinny być one budowane na trasach przelotu ptaków lub na obszarach gniazdowania wrażliwych w tym aspekcie gatunków (Everaert, Stienen 2007). Farmy wiatrowe stają się także miejscem zimowania inwazyjnego gatunku biedronki azjatyckiej (Harmonia axyridis; Dudek, Dudek, Tryjanowski 2015). Gatunek ten obserwowany jest często w dużych zagregowanych koloniach w trakcie 
spoczynku zimowego na obiektach pochodzenia antropogenicznego. Wiatraki stanowią dla tych chrząszczy atrakcyjne miejsce w otwartym terenie, ponieważ wykazują zwykle większą temperaturę od otaczającego środowiska i chronią od wiatru (Dudek, Dudek, Tryjanowski 2015). Coraz częściej wskazuje się na pozytywne aspekty oddziaływania antropogenicznych elementów krajobrazu na przyrodę. Struktury od dawna związane z krajobrazem rolniczym mają szczególnie duże znaczenie w tym kontekście. Tradycyjna zabudowa wraz z jej najbliższym otoczeniem dostarcza wielu cennych miejsc lęgowych i żerowiskowych (Hiron $\mathrm{i}$ in. 2013b; Rosin i in. 2016b). Jednakże towarzyszące osiedlom ludzkim zwierzęta, takie jak psy lub koty, oddziałują negatywnie na populacje ptaków, szczególnie gatunków gniazdujących na ziemi (Söderström, Pärt, Rydén 1998; Sims i in. 2008). Wraz z rozwojem wsi oraz zmianami społeczno-ekonomicznymi zmienia się charakter zabudowy: rośnie udział zmodernizowanych gospodarstw rolnych i nowych gospodarstw wykorzystywanych wyłącznie do celów mieszkalnych. Nowa architektura i sposób zagospodarowania przestrzeni w gospodarstwach nie sprzyjają różnorodności biologicznej, ponieważ charakteryzują się zredukowaną liczbą cennych siedlisk w porównaniu do tradycyjnej zabudowy (Rosin i in. 2016b). Ważna zatem w kontekście ochrony różnorodności biologicznej staje się ochrona zabudowy wiejskiej (Rosin i in. 2016b).

\subsection{Znaczenie siedlisk nieużytkowanych rolniczo}

26. Jaką rolę odgrywają elementy krajobrazu rolniczego (np. śródpolne oczka wodne) dla zachowania różnorodności gatunkowej i krajobrazowej?

27. Jaki jest najlepszy termin koszenia łąk i torfowisk dla zachowania różnorodności gatunkowej?

28. Jak w inny sposób można zagospodarowywać produkty z obszarów objętych ochroną, które z powodu ochrony siedlisk mają małą wartość dla zwierząt hodowlanych?

29. Jak wygląda w Polsce problem gatunków inwazyjnych i czy rolnictwo odgrywa dużą rolę w ich rozprzestrzenianiu?

Heterogeniczność siedlisk nieużytkowanych rolniczo (śródpolnych zadrzewień, krzewów, zbiorników wodnych, miedz) jest jednym z kluczowych czynników kształtujących poziom różnorodności biologicznej krajobrazu rolniczego (np. Duelli, Obrist 2003; Billeter i in. 2008). Intensyfikacja rolnictwa doprowadziła do fragmentacji i zanikania tych siedlisk, czego konsekwencją jest spadek liczebności wielu gatunków ptaków, np. trznadla, cierniówki, gąsiorka (Chodkiewicz i in. 2013). Charakterystycznym elementem są np. śródpolne zbiorniki wodne. Mają one zwykle poniżej 1 ha i okresowo wysychają. Niestety, są one także często 
zanieczyszczone (Pawlaczyk i in. 2001). Śródpolne oczka wodne są ostoją różnorodności biologicznej. Stanowią siedlisko dla płazów, wielu gatunków ptaków oraz bezkręgowców. Regulują mikroklimat, oddziałując na cały agroekosystem (Surmacki 2005; Sayer i in. 2012). Dobrze poznane jest ich znaczenie dla zwierząt wodnych, w tym ptaków. O różnorodności biologicznej śródpolnych stawów decyduje także struktura otaczającego krajobrazu (Surmacki 2005) oraz skład gatunkowy roślinności i stopień pokrycia roślinnością (Davies i in. 2016). Ekstensywna działalność rolnicza na terenach cennych przyrodniczo jest często wręcz konieczna dla zachowania różnorodności biologicznej. Regularne koszenie łąk i torfowisk w odpowiednim czasie jest kluczowe dla wielu gatunków zwierząt, m.in. ptaków (Broyer 2009), motyli (Bruppacher i in. 2016) oraz pajęczaków (Bell, Wheater, Cullen 2001). Kalendarz koszenia musi być dopasowany do danego regionu, typu siedliska i wymagań gatunków zasiedlających dany habitat (Brown, Nocera 2017). Terminy koszenia realizowane w ramach programów rolnośrodowiskowych są podyktowane wymaganiami wybranych gatunków ptaków, co wiąże się z koszeniem po zakończeniu sezonu lęgowego. Negatywnym efektem koszenia w późniejszym terminie jest zbiór siana gorszej jakości. Potrzebne jest więc opracowanie efektywnych ekonomicznie sposobów jego użytkowania.

Ważnym problemem w ochronie terenów rolnych jest szerzenie się gatunków inwazyjnych. W 2014 r. została przyjęta lista inwazyjnych gatunków roślin i zwierząt, wskazująca 37 gatunków będących istotnym zagrożeniem dla bioróżnorodności w skali UE (załącznik Rozporządzenia Nr 1143/2014). Uważa się, że obecność inwazyjnych gatunków przyczynia się do 10-procentowej straty globalnego produktu brutto. Straty te są powodowane niszczeniem przez te gatunki upraw rolniczych, a w wyliczeniach uwzględniane są także nakłady mające zapobiegać tym zdarzeniom (Solorz 2012).

Ogólnym skutkiem występowania gatunków inwazyjnych są zakłócenia w systemach ekologicznych (Skorupski 2016). Wiedza, jaką dysponujemy na ten temat, jest jednak cały czas niewielka i ogranicza się do kilku gatunków. Do tych najsilniej oddziaływujących na środowisko należy zaliczyć wizona amerykańskiego (dawniej norkę amerykańską, Neovision vison), szopa pracza (Procyon lotor) i jenota (Nyctereutes procyonoides). Liczebność tych drapieżników wzrasta, co negatywnie oddziałuje na populacje ptaków wodno-błotnych (Zalewski 2012). Gatunki te charakteryzują się wysoką zdolnością przystosowawczą, dużym potencjałem reprodukcyjnym oraz brakiem naturalnych wrogów, co skazuje walkę z tymi gatunkami na duże niepowodzenia. Praca nad redukowaniem gatunków inwazyjnych jest bezwzględnie konieczna, mimo że wskazuje się również na pozytywne efekty niektórych gatunków, np. nawłoć kanadyjska (Solidago canadensis) może wpływać lokalnie korzystnie na liczebność niektórych pajęczaków i owadów zapylających 
(Dudek i in. 2016). Obecność gatunków inwazyjnych może mieć bezpośrednie negatywne znaczenie dla człowieka. Barszcz Sosnowskiego (Heracleum sosnowskyi) i ambrozja (Ambriosia sp.) na terenie Polski stanowią poważne zagrożenie dla zdrowia człowieka (Tokarska-Guzik i in. 2012).

\section{Podsumowanie i wnioski}

W pracy przedstawiono problemy badawcze, które dotyczą ochrony bioróżnorodności krajobrazu rolniczego w Polsce. Zebranie i usystematyzowanie literatury oraz opinii naukowców na ten temat jest ważnym krokiem, ponieważ tylko dzięki gruntownej rewizji stanu wiedzy możliwe jest prowadzenie adekwatnych działań. Podejmowane działania powinny opierać się na dowodach, a te dotychczas realizowane - podlegać ocenie (Sutherland i in. 2004). Dla zwiększenia efektywności tych działań kluczowe jest zbudowanie dialogu na linii polityka-nauka (Young i in. 2014). Pomiędzy decydentami a przedstawicielami nauki powinna zachodzić ciągła wymiana myśli i wyników badań, a omawiane w tekście publikacji problemy powinny być uszczególawiane i rozwiązywane, także w postaci stosownych aktów prawnych.

Intensyfikacja rolnictwa uczyniła produkcję żywności bardziej opłacalną ekonomicznie i wydajną, ale przyczyniła się do wielu negatywnych zmian w przyrodzie (Matson i in. 1997). Te zachodzące w krajobrazie rolniczym prowadzą do utraty gatunków związanych z ekstensywnie prowadzonym rolnictwem (Tryjanowski i in. 2011). Współczesnym wyzwaniem dla rolnictwa jest zatem pogodzenie produkcji żywności z ograniczaniem jego wpływu na środowisko (Seufert, Ramankutty, Foley 2012). Programy rolnośrodowiskowe zachęcające rolników do ekstensywnego gospodarowania (Sawicka, Hameed, Noaema 2016) nie powstrzymały spadku liczebności ptaków na terenach rolniczych (Żmihorski i in. 2016) i nie przyniosły efektu w innych krajach UE (Batary i in. 2015). Proponowane są różne inne rozwiązania, do których należy m.in. stosowanie praktyk agroekologicznych (Wezel i in. 2014). Kolejny wariant rozwoju zakłada podział obszarów rolniczych na te uprawiane intensywnie oraz ekologicznie (ekstensywnie; Leifeld 2016). Wiedza na temat wpływu różnych rozwiązań przestrzennych oraz praktyk agrotechnicznych na przyrodę i wydajność produkcji rolniczej jest stale niekompletna, stąd obecnie prowadzone są intensywne badania w tym zakresie (np. Flohre i in. 2011; Fahrig $i$ in. 2015; Hiron i in. 2015). Kolejny obszar wymagający zrozumienia to relacja pomiędzy czynnikami społecznymi i poziomem bioróżnorodności (Naeem i in. 2016). W tym kontekście warto podkreślić, że wzrost świadomości polskiego społeczeństwa w kwestii potrzeby ochrony przyrody jest konieczny. Jednakże niezależnie od naszej wiedzy i działań w tym zakresie na kształt rolnictwa oddziaływać 
będą również zmieniający się klimat (Nelson i in. 2014) oraz problemy związane z wyczerpywaniem się paliw kopalnych (Bardi, El Asmar, Lavacchi 2013).

Problem ochrony różnorodności biologicznej krajobrazu rolniczego w Polsce (i nie tylko) powinien być rozpatrywany bardzo szeroko i na różnych poziomach organizacji - od jednostki (pojedynczej osoby), poprzez czynniki lokalne, krajobraz, po te dotyczące całych regionów. Liczne, dobrze publikowane prace mają szanse skutecznie korygować Wspólną Politykę Rolną UE, która jest słabo dostosowana do warunków środowiskowych, jakie panują w Polsce i innych krajach Europy Środkowej. Badania naukowe powinny dostarczać odpowiedzi, w jaki sposób powinno się kształtować zasoby naturalne i zarządzać nimi (Sutherland i in. 2013).

Kluczem do poprawy efektywności ochrony przyrody krajobrazu rolniczego jest zrozumienie, że zachowanie wysokiego poziomu różnorodności biologicznej jest w interesie wszystkich, rolników oraz reszty społeczeństwa. Wysoki poziom bioróżnorodności zapewnia szeroką gamę funkcji ekosystemowych (dostarczanie paliw, żywności, regulacja klimatu, kontrola biologiczna, rekreacja i wiele innych; Rosin i in. 2011), bez których potrzeby ludzkości nie mogą zostać zaspokojone, a rozwój cywilizacji jest niemożliwy w dłuższej perspektywie (Cardinale i in. 2012). Powszechne zrozumienie tego faktu jest bezwzględnie konieczne, tak aby możliwe było wypracowanie wspólnej płaszczyzny w obszarze ochrony przyrody pomiędzy naukowcami, osobami decyzyjnymi i społeczeństwem.

\section{Podziękowania}

Serdecznie dziękujemy za pomoc w przeprowadzeniu badań ankietowych i za cenne uwagi doktorowi Jarosławowi Stalędze. Dziękujemy za pomoc i udział w badaniach Weronice Banaszak-Cibickiej, Katarzynie Bańkowskiej, Agacie Bednarek, Urszuli Biereżnoj-Bazille, Sławomirowi Chmielewskiemu, Zygmuntowi Dajdokowi, Alexi Danyłow, Andrzejowi Dombrowskiemu, Krzysztofowi Dudkowi, Arturowi Goławskiemu, Bartłomiejowi Gołdynowi, Izabeli Hajdamowicz, Andrzejowi Jankuszewowi, Janowi Jedlikowskiemu, Andrzejowi Kazuniowi, Jakubowi Kosickiemu, Henrykowi Kotowi, Krzysztofowi Kujawie, Mariuszowi Kulikiemu, Zbigniewowi Kwiecińskiemu, Magdalenie Lendzie, Damianowi Łowickiemu, Annie Matuszczak, Andrzejowi Mizgajskiemu, Łukaszowi Nicewiczowi, Markowi Nieoczymowi, Sylwii Pustkowiak, Pawłowi Radzikowskiemu, Marcie Sawadro, Pawłowi Sienkiewiczowi, Marioli Staniak, Marzenie Stańskiej, Krzysztofowi Stasiakowi, Beacie Szewczyk, Pawłowi Szymańskiemu, Marcinowi Tobółce, Łukaszowi Trębickiemu, Andrzejowi Wuczyńskiemu, Jackowi Zajączkowskiemu. 


\section{Bibliografia}

Alstion J.A., Pardey P.G. (2014). Agriculture in the global economy. Journal of Economic Perspectives, 28, 121-146.

Bajda J. (1995). Grzech ekologiczny (Próba podejścia do zagadnienia). W: B. Wójtkiewicz (red.). Z człowiekiem i przyroda (wreszcie) po ludzku (s. 71-80). Wisełka: Centrum Ekologiczno-Rekolekcyjne „Przymierze”.

Bański J. (2014). Perspektywy rozwoju polskiej wsi - wybrane zagadnienia. Wieś i Rolnictwo, $4,87-100$.

Bardi U., El Asmar T., Lavacchi A. (2013). Turning electricity into food: The role of renewable energy in the future agriculture. Journal Clean Production, 53, 224-231.

Barrios L., Rodriguez A. (2004). Behavioural and environmental correlates of soaring-bird mortality at on-shore wind turbines. Journal of Applied Ecology, 41, 72-81.

Batary P., Dicks L.V., Kleijn D., Sutherland W.J. (2015). The role of agri-environment schemes in conservation and environmental management. Conservation Biology, 29, 1006-1016.

Bell J.R., Wheater C.P., Cullen W.R. (2001). The implications of grassland and heatland management for the conservation of spider communities: A review. Journal of Zoology, 225, 377-387.

Benton T.G., Bryant D.M., Cole L., Crick H.Q.P. (2002). Linking agricultural practice to insect and bird populations: A historical study over three decades. Journal of Applied Ecology, 39, 673-687.

Benton T.G., Vickery J.A., Wilson, J.D. (2003). Farmland biodiversity: Is habitat heterogeneity the key? Trends in Ecology \& Evolution, 18, 182-188.

Bernacka H., Niedźwiecki P., Kasperska D., Peter E. (2013). The behavior of breed sheep Wrzosówka on the xerothermic grasslands. Przegląd Hodowlany, 4, 21-24.

Billeter R., Liira J., Bailey D., Bugter R., Arens P., Augenstein I. i in. (2008). Indicators for biodiversity in agricultural landscapes: A pan-European study. Journal of Applied Ecology, 45, 141-150.

Birkhofer K., Smith H.G., Rundlöf M. (2016). Environmental impacts of organic farming. eLS. $1-7$.

Boguszewski R. (2013). Wartości i normy. Komunikat z badań. CBOS, 1-7.

Breeuwer A., Berendse F., Willems F., Foppen R., Teunissen W., Schekkerman H., Goedhart P. (2009). Do meadow birds profit from agri-environment schemes in Dutch agricultural landscapes? Biological Conservation, 142, 2949-2953.

Broom D.M., Galindo F.A., Murgueitio E. (2013). Sustainable, efficient livestock production with high biodiversity and good welfare for animal. Proceedings of the Royal Society of London B: Biological Science, 280, 2013-2025.

Brown L.J., Nocera J.J. (2017). Conservation of breeding grassland birds requires local management strategies when hay maturation and nutritional quality differ among regions. Agriculture, Ecosystems \& Environment, 237, 242-249.

Broyer Ã. (2009). Whinchat Saxicola rubetra reproductive success according to hay cutting schedule and meadow passerine density in alluvial and upland meadows in France. Journal for Nature Conservation, 17, 160-167. 
Bruppacher L., Pellet J., Arlettaz R., Humbert J. (2016). Simple modifications of mowing regime promote butter flies in extensively managed meadows: Evidence from field-scale experiments. Biological Conservation, 196, 196-202.

Cardinale B.J., Duffy J.E., Gonzalez A., Hooper D.U., Perrings C., Venail P., Narwani A., Mace G.M., Tilman D., Wardle D.A., Kinzig A.P., Daily G.C., Loreau M., Grace J.B., Larigauderie A., Srivastava D.S., Naeem S. (2012). Biodiversity loss and its impact on humanity. Nature, 486, 59-67.

Carrasco S., Ripoll G., Panea B., Alvarez-Rodrigues J., Joy M. (2009). Carcass tissue composition in light lambs: Influence of feeding system and prediction equations. Livestock Science, 126, 112-121.

Cassandro M. (2014). Extensive animal production and its added value in production and environmental chains: A dairy cattle study. Przegląd Hodowlany, 5, 1-4.

CBD (2014). Convention on Biological Diversity. Fifth national report on the implementation of the Convention on Biological Diversity. Warsaw, Poland.

Chodkiewicz T., Neubauer G., Chylarecki P., Sikora A., Cenian Z., Ostasiewicz M., Wylegała P., Ławicki Ł., Smyk B., Betleja J., Gaszewski K., Górski A., Grygoruk G., Kajtoch Ł., Kata K., Krogulec J., Lenkiewicz W., Marczakiewicz P., Nowak D., Pietrasz K., Rohde Z., Rubacha S., Stachyra P., Świętochowski P., Tumiel T., Urban M., Wieloch M., Woźniak B., Zielińska M., Zieliński P. (2013). Monitoring populacji ptaków Polski w latach 20122013. Biuletyn Monitoringu Przyrody, 11, 1-72.

Chylarecki P., Jawińska D., Kuczyński L. (2006). Monitoring Pospolitych Ptaków Legowych Raport $z$ lat 2003-2004. Warszawa: OTOP.

Davies S.R., Sayer C.D., Greaves H., Siriwardena G.M., Axmacher J.C. (2016). A new role for pond management in farmland bird conservation. Agriculture, Ecosystems \& Environment, 233, 179-191.

Dmochowska H. (2014). Rocznik Statystyczny Rolnictwa. Warszawa: Główny Urząd Statystyczny.

Dołęga J. (1997). Zagadnienia teologiczne w problematyce teologicznej. Studia Teologiczne, 5, 277-286.

Dudek K., Dudek M., Tryjanowski P. (2015). Wind Turbines as Overwintering Sites Attractive to an Invasive Lady Beetle, Harmonia axyridis Pallas (Coleoptera: Coccinellidae). The Coleopterists Bulletin, 69, 665-669.

Dudek K., Michlewicz M., Dudek M., Tryjanowski P. (2016). Invasive Canadian goldenrod (Solidago canadensis L.) as a preferred foraging habitat for spiders. Arthropod-Plant Interactions, 10 (5), 777-381.

Duelli P., Obrist M.K. (2003). Regional biodiversity in an agricultural landscape: The contribution of seminatural habitat islands. Basic and Applied Ecology, 4, 129-138.

EURO-Lex. (2016). Purchasing property in other EU countries. http://eur-lex.europa.eu/ legal-content/EN/TXT/?uri=URISERV\%3Al24404 [dostęp: 30.07.2017].

Everaert J., Stienen E.W.M. (2007). Impact of wind turbines on birds in Zeebrugge (Belgium). Significant effect on breeding tern colony to collisions. Biodiversity and Conservation, $16,3345-3359$. 
Fahrig L., Girag J., Duro D., Pasher J., Smith A., Javorek S., King D., Lindsay K.F., Mitchell S., Tischendorf L. (2015). Farmland with smaller crop fields have higher within-field biodiversity. Agriculture, Ecosystems \& Environment, 200, 219-234.

Fischer J., Hartel T., Kuemmerle T. (2012). Conservation policy in traditional farming landscapes. Conservation Letters, 5, 167-175.

Flohre A., Fischer C., Aavik T., Bengtsson J., Berendse F., Bommarco R., Ceryngier P., Clement L.W., Dennis C., Eggers S., Emmerson M., Geiger F., Guerrero I., Hawro V., Inchausti P., Liira J., Morales M.B., Onate J.J., Pärt T., Weisser W.W., Winqvist C., Thies C., Tscharntke T. (2011). Agricultural intensification and biodiversity partitioning in European landscapes comparing plants, carabids, and birds. Ecological Applications, 21, 1772-1781.

Gagic V., Bartomeus I., Jonsson T., Taylor A., Winqvist C., Fisher C., Slade E.M., Steffan-Dewenter I., Emmerson M., Potts S.G., Tscharntke T., Weisser W., Bommarco R. (2015). Functional identity and diversity of animals predict ecosystem functioning better than species-based indices. Proceedings of the Royal Society of London B: Biological Science, 282, 2014-2620.

Gagné S.A., Fahrig L. (2011). Do birds and beetles show similar responses to urbanization? Ecological Applications, 21, 2297-2312.

Gibbons D.W., Wilson J.D., Green R.E. (2011). Using conservation science to solve conservation problems. Journal of Applied Ecology, 48, 505-508.

Groot R. de, Brander L., Ploeg S. van der, Costanza R., Bernard F., Braat L., Christie M., Crossman N., Ghermandi A., Hein L., Hussain S., Kumar P., McVittie A., Portela R., Rodriguez L.C., Brink P. ten, Beukering P. van (2012). Global estimates of the value of ecosystems and their services in monetary units. Ecosystem Services, 1, 50-61.

Gruszecki T.M., Krupiński J. (2016). Potencjał ras rodzimych w produkcji zwierzęcej i kształtowaniu ekosystemów trawiastych. Ogólnopolska Konferencja Naukowa „Ekosystemy trawiaste w kształtowaniu i ochronie środowiska”, Urszulin, 1-3 czerwca 2016.

GUS (2013a). Powszechny Spis Rolny 2010. Warszawa, Olsztyn.

GUS (2013b). Ludność. Stan i Struktura demograficzno-społeczna. Warszawa: Zakład Wydawnictw Statystycznych.

GUS (2016). Pogłowie bydła i owiec według stanu w czerwcu 2016 r. Opracowanie sygnalne. Warszawa.

Hiron M., Berg Å., Eggers S., Josefsson J., Pärt T. (2013a). Bird diversity relates to agrienvironment schemes at local and landscape level in intensive farmland. Agriculture, Ecosystems \& Environment, 176, 9-16.

Hiron M., Berg Å., Eggers S., Pärt T. (2013b). Are farmsteads over-looked biodiversity hotspots in intensive agricultural ecosystems? Biological Conservation, 159, 332-342.

Hiron M., Berg Å., Eggers S., Berggren Å., Josefsson J., Pärt T. (2015). The relationship of bird diversity to crop and non-crop heterogeneity in agricultural landscapes. Landscape Ecology, 30, 2001-2013.

Kaługa I., Sparks T.H., Tryjanowski P. (2011). Reducing death by electrocution of the white stork Ciconia ciconia. Conservation Letters, 4, 483-487.

Kotowska D., Żmihorski M. (2016). Wyniki monitoringu ornitologicznego w 2015 roku. Zakres prac zrealizowanych $w 2015$ roku oraz wstępne wyniki monitoringu efektów pro- 
gramu rolnośrodowiskowego w zakresie ornitofauny. Falenty: Instytut Technologiczno-Przyrodniczy.

Lachmann L., Marczakiewicz P., Grzywaczewski G. (2010). Protecting Aquatic Warblers (Acrocephalus paludicola) through a landscape-scale solution for the management of fen peat meadows in Poland. Grassland Science in Europe, 15, 711-713.

Leddy K.L., Higgins K.F., Naugle D.E. (1999). Effects of wind turbines on upland nesting birds in conservation reserve program grasslands. The Wilson Bulletin. 111, 100-104.

Leifeld J. (2016). Current approaches neglect possible agricultural cutback under large-scale organic farming. A comment to Ponisio et al. Proceedings of the Royal Society of London B: Biological Science, 283.

LIFE (2016). Life Programme. Life Projects. Project database. http://ec.europa.eu/environ$\mathrm{ment} /$ life/project/Projects/index.cfm?fuseaction=home.search\&cfid=586490\&cftoken =9e9fb5b490b3ce95-8DF915BA-B541-154B-5F32AB837EB08826 [dostęp: 18.01.2017].

Marja R., Herzon I., Viik E., Elts J., Mänd M., Tscharntke T., Batáry P. (2014). Environmentally friendly management as an intermediate strategy between organic and conventional agriculture to support biodiversity. Biological Conservation, 178, 146-154.

Matson P.A., Parton W.J., Power A.G., Swift M.J. (1997). Agricultural intensification and ecosystem properties. Science, 277, 504-509.

Morelli F., Møller A.P. (2015). Concerns about the use of ecosystem services as a tool for nature conservation: From misleading concepts to providing a "price" for nature, but not a "value". European Journal of Ecology, 1, 68-70.

Mroczek J.R., Kostecka J., Korczy M., Roli O., Rolno P. (2013). Ocena roli programu rolnośrodowiskowego w postrzeganiu przez rolników wybranych aspektów problematyki środowiskowej. Inżynieria Ekologiczna, 34, 189-197.

Mroczkowski S. (2005). Role of sheep husbandry in conservation of cultural and natural heritage. W: Z. Mirek, A. Nikel, W. Paul (red.). Biologiczne i kulturowe aspekty gospodarki owczarskiej (s. 129-135). Kraków: Akademia Rolnicza w Krakowie, Instytut Botaniki PAN w Krakowie.

Naeem S., Chazdon R., Duffy E., Prager C., Worm, B. (2016). Biodiversity and human well-being: An essential link for sustainable development. Proceedings of the Royal Society B, 283, 2016-2091.

Naidoo R., Iwamura T. (2007). Global-scale mapping of economic benefits from agricultural lands: Implications for conservation priorities. Biological Conservation, 140, 40-49.

Nelson G.C., Mensbrugghe D. van der, Ahammad H., Blanc E., Calvin K., Hasegawa T., Havlik P., Heyhoe E., Kyle P., Lotzen-Campen H., Lampe M. von, d'Croz D.M., Meijl H. van, Muller C., Reilly J., Robertson R., Sands R.D., Schmitz C., Tabeau A., Takahashi K., Valin H., Willenbockel D. (2014). Agriculture and climate change in global scenarios: Why don't the models agree. Agricultural Economics, 45, 85-101.

Neubauer G., Chodkiewicz T., Chylarecki P. (2014). Sprawozdanie z monitoringu ptaków Polski. Monitoring ptaków w tym monitoring obszarów specjalnej ochrony ptaków Natura 2000. Etap V. Marki: OTOP

Neubauer G., Meissner W., Chylarecki P., Chodkiewicz T., Sikora A., Pietrasz K., Cenian Z., Betleja J., Gaszewski K., Kajtoch Ł., Lenkiewicz W., Ławicki Ł., Rohde Z., Rubacha S., 
Smyk B., Wieloch M., Wylegała P., Zielińska M., Zieliński P. (2015). Monitoring Ptaków Polski w latach 2013-2015. Biuletyn Monitoringu Przyrody, 13, 1-92.

Newton I. (2004). The recent declines of farmland bird populations in Britain: An appraisal of causal factors and conservation actions. Ibis, 146, 579-600.

Niżnikowski R., Szymańska Ż., Majdański S., Głuchowski Ł., Ślęzak M., Świątek M. (2015). Kazimierzowska goats - a native breed of the Middle Vistula River Valley. Przegląd Hodowlany, 3, 23-24.

Pawlaczyk P., Wołejko L., Jermaczek A., Stańko R. (2001). Poradnik ochrony mokradeł. Świebodzin: Wydawnictwo Klubu Przyrodników.

Peters K.J. (2006). Sheep and goat production in Central and Eastern Countries. REU Technical Series, 50, 272-277.

Pinto-Correia T., Mascarenhas J. (1999). Contribution to the extensification/intensification debate: New trends in the Portugese montado. Landscape and Urban Planning, $46,125-131$.

Pisarek M., Krochmal-Marczak B., Dykiel M., Sieczkowska L., Klamut M. (2016). Decyzje produkcyjne rolników z gmin Haczów i Korczyna (woj. podkarpackie) i ich wpływ na środowisko przyrodnicze. Progress in Economic Sciences, 3, 185-199.

Ponsio L.C., Kremen C. (2016). System-level approach needed to evaluate the transition to more sustainable agriculture. Proceedings of the Royal Society of London B: Biological Science, 283.

Pullin A.S., Baldi A., Can O.E., Dieterich M., Kati V., Livoreil B., Lovei G., Mihok B., Nevin O., Selva N., Sousa-Pinto I. (2009). Conservation focus on Europe: Major conservation policy issues that need to be informed by conservation science. Conservation Biology, 23, 818-824.

Putfarken D., Dengler J., Lehmann S., Härdtle W. (2008). Site use of grazing cattle and sheep in a large-scale pasture landscape: A GPS/GIS assessment. Applied Animal Behaviour Science, 111, 54-67.

Rosin Z.M., Takacs V., Báldi A., Banaszak-Cibicka W., Dajdok Z., Dolata P.T., Kwieciński Z., Łangowska A., Moroń D., Skórka P., Tobółka M., Tryjanowski P., Wuczyński A. (2011). Ecosystem services as an efficient tool of nature conservation: A view from the Polish farmland. Chrońmy Przyrodę Ojczysta, 67, 3-20.

Rosin Z.M., Skórka P., Part T., Żmihorski M., Ekner-Grzyb A., Kwieciński Z., Tryjanowski P. (2016a). Villages and their old farmseads are hot spots of bird diversity in agricultural landscapes. Journal of Applied Ecology, 53, 1363-1372.

Rosin Z.M., Skórka P., Szymański P., Tobolka M., Luczak A., Tryjanowski P. (2016b). Constant and seasonal drivers of bird communities in a wind farm: implications for conservation. PeerJ, 4, e2105.

Saidur R., Rahim N.A., Islam M.R., Solangi K.H. (2011). Environmental impact of wind energy. Renewable \& Sustainable Energy Reviews, 15, 2423-2430.

Sawicka B., Hameed T.S., Noaema A.H. (2016). Evaluation of agri-environmental programs used by farmers in south-eastern Poland. Acta Scientiarum Polonorum. Agricultura, $15,37-54$. 
Sayer C.D., Andrews K., Shilland E., Edmonds N., Edmonds-Brown R., Patmore I.R., Emson D., Axmacher J.C. (2012). The role of pond management for biodiversity conservation in an agricultural landscape. Aquatic Conservation: Marine and Freshwater Ecosystems, 22, 626-638.

Seufert V., Ramankutty N., Foley J.A. (2012). Comparing the yields of organic and conventional agriculture. Nature, 485, 229-232.

Sims V., Evans K.L., Newson S.E., Tratalos J.A., Gaston J.K. (2008). Avian assemblage structure and domestic cat densities in urban environments. Diversity and Distributions, $14,387-399$.

Skorupski J. (2016). Ochrona przyrody a inwazja norki amerykańskiej (Neovison vison) w Polsce - krytyczna analiza problemu. SYLWAN, 160, 79-87.

Small R.W. (2002). Role of rare and traditional breeds in conservation: The Grazing Animal Project. Proceedings of the farm animal genetic resources: BSAS/ DEFRA/RBTS/ Sheep Trust Conference, Edinburgh, 26-27 listopada.

Söderström B., Pärt T., Rydén J. (1998). Different nest predator faunas and nest predation risk on ground and shrub nests at forest ecotones: An experiment and a review. Oecologia, 117, 108-118.

Solorz W. (2012). Przyczyny i skutki inwazji biologicznych na świecie i w Polsce. Studia i Materiały CEPL w Rogowie, 33, 9-14.

Štefanová M., Šálek M. (2014). Effects of integrated farming on herbal and bird species diversity in Czech agricultural landscapes. Polish Journal of Ecology, 62, 161-176.

Surmacki A. (2005). Habitat use by three Acrocephalus warblers in an intensively used farmland area: The influence of breeding patch and its surroundings. Journal of Ornithology, 146, 160-166.

Sutherland W.J., Pullin A.S., Dolman P.M., Knight T.M. (2004). The need for evidence-based conservation. Trends in Ecology \& Evolution, 19, 305-308.

Sutherland W.J., Fleishman E., Mascia M.B., Pretty J., Rudd M.A. (2011). Methods for collaboratively identifying research priorities and emerging issues in science and policy. Ecology and Evolution, 2, 238-247.

Sutherland W.J., Freckleton R.P., Godfray C.J., Beissinger S.R., Benton T., Cameron D.D., Carmel Y., Coomes D.A., Coulson T., Emmerson M.C., Hails Rosemary S., Hays G.C. (2013). Identification of 100 fundamental ecological questions. Journal of Ecology, $101,58-67$.

Szulc K. (2011). Protection of genetic resources of farm animals in the context of sustainable development. Problemy Ekorozwoju, 6, 141-146.

Szymański P., Deoniziak K., Łosak K., Osiejuk T.S. (2017). The song of skylarks Alauda arvensis indicates the deterioration of an acoustic environment resulting from wind farm start-up. Ibis, 159, 769-777

Tokarska-Guzik B., Dajdok Z., Zając M., Zając A., Urbisz A., Danielewicz W., Hołdyński C. (2012). Rośliny obcego pochodzenia w Polsce ze szczególnym uwzględnieniem gatunków inwazyjnych. Warszawa: Wydawnictwo Generalnej Dyrekcji Ochrony Środowiska.

Tryjanowski P., Hartel T., Báldi A., Szymański P., Tobolka M., Herzon I., Goławski A., Konvicka M., Hromada M., Jerzak L., Kujawa K., Lenda M., Orłowski G., Panek M., 
Skórka P., Sparks T.H., Tworek S., Wuczyński A., Żmihorski M. (2011). Conservation of farmland birds faces different challenges in Western and Central-Eastern Europe. Acta Ornithologica, 46, 1-12.

Tryjanowski P., Sparks T.H., Jerzejak L., Rosin Z., Skórka P. (2014). A Paradox for conservation: Electricity pylons may benefit avian diversity in intensive farmland. Conservation Letters, 7, 34-40.

Vicini J., Etherton T., Kris-Etherton P., Ballam J., Denham S., Staub R., Goldstein D., Cady R., McGrath M., Lucy M. (2008). Survey of retail milk composition as affected by label claims regarding farm-management practices. Journal of the American Dietetic Association, 108, 1198-1203.

Wezel A., Casagrande M., Celette F., Vian J-F. Ferrer A., Peigne J. (2014). Agroecological practices for sustainable agriculture. A review. Agronomy for Sustainable Development, 34, 1-20.

Whittingham M.J. (2011). The future of agri-environment schemes: biodiversity gains and ecosystem services delivery? Journal of Applied Ecology, 48, 509-513.

Wilk T., Jujka M., Krogulec J., Chylarecki P. (2010). Ostoje ptaków o znaczeniu międzynarodowym $w$ Polsce. Marki: OTOP.

Wolters V., Bengtsson J., Zaitsev A.S. (2006). Relationship among the species richness of different taxa. Ecology, 87, 1886-1895.

Young J.C., Waylen K.A., Sarkki S., Albon S., Bainbridge I., Balian E., Davidson J., Edwards D., Fairley R., Margerison C., McCracken D., Owen R., Quine C. P., Stewart-Roper C., Thompson D., Tinch R., Van den Hove S., Watt A. (2014). Improving the science-policy dialogue to meet the challenges of biodiversity conservation: having conservations rather than talking at one-another. Biodiversity and Conservation, 23, 387-404.

Zalewski D. (2012). Strategia Polskiego Związku Łowieckiego w postępowaniu z gatunkami obcymi w ekosystemach leśnych. Studia i Materiały CEPL w Rogowie, 33, 304-318.

Załącznik rozporządzenia Nr 1143/2014. Regulation (EU) No 1143/2014 of the European Parliament and of the Council of 22 October 2014 on the prevention and management of the introduction and spread of invasive alien species.

Zbyryt A., Menderski S., Niedźwiecki S., Kalski R. (2014). Populacja lęgowa bociana białego Ciconia ciconia w OSO Ostoi Warmińskiej. Ornis Polonica, 55, 240-256.

Zbyryt A., Kapowicz E., Kapowicz R., Zub K. (2016). Liczebność, zagęszczenie i sukces lęgowy orlika krzykliwego Clanga pomarina w Puszczy Knyszyńskiej w latach 1999-2015. Ornis Polonica, 57, 237-247.

Ziętara W. (2014). Koncentracja i specjalizacja gospodarstw rolniczych w procesie integracji z Unią Europejską. Zeszyty Naukowe Szkoły Głównej Gospodarstwa Wiejskiego w Warszawie - Problemy Rolnictwa Światowego, 14, 157-169.

Żmihorski M., Kotowska D., Berg Å., Pärt T. (2016). Evaluating conservation tools in Polish grasslands: The occurrence of birds in relation to agri-environment schemes and Natura 2000 area. Biological Conservation, 194, 150-157.

Żmija J., Szafrańska M. (2015). Społeczne i ekonomiczne aspekty funkcjonowania drobnych gospodarstw rolnych w Polsce. Wieś i Rolnictwo, 1, 155-165. 


\title{
How to Keep a High Level of Biodiversity on Farmland Area in Poland? Identification of Major Research Problems
}

\begin{abstract}
Farmland areas account for $60 \%$ of the total area of Poland and they are among those featuring the highest level of biodiversity in Europe. However, the high position in the ranking is threatened. The aim of the study is to identify key research problems which help protect the natural environment of Polish rural areas. To this end research questions were addressed to 45 scientists and experts in the field. Their answers were assigned to one of seven categories: assessment of biodiversity condition, protection policy effectiveness, choice between traditional and intensive farming, factors influencing farmer decisions, livestock importance, the importance of buildings and infrastructure and the importance of micro-habitats for biodiversity conservation. The problems are presented in a general form and we hope that they will contribute as a significant introduction to further discourse between policy makers and scientists. Starting a debate of this kind is crucial for effective conservation of the natural resources of Polish agricultural landscape.
\end{abstract}

Keywords: agricultural landscape, rural areas, nature conservation, biodiversity decline. 